\title{
Using Authentic Materials \\ to Teach Reading Comprehension ${ }^{1}$
}

\author{
Ana Rojas Ugalde \\ I Iniversidad Nacional, Costa Rica
}

\section{RESUMEN}

Se estudia el uso de textos auténticos y la elaboración de materiales para la enseñanza y aprendizaje de la comprensión de lectura. Se presenta un análisis de la información y de las teorías aceptadas por los expertos del área y su congruencia con los materiales que se encuentran en el mercado. Además, se analizan los intereses y necesidades de los estudiantes de la Universidad Nacional con el fin de que los profesores cuenten con las herramientas para identificar los textos más significativos para los estudiantes y así mejorar sus habilidades de lectura.

\begin{abstract}
The use of authentic texts is addressed for teaching reading comprehension as well as for creating materials to improve the teaching-learning process of this skill. The information and theories held by the experts in this field are discussed with regard to whether they correspond to the materials available in the market. In addition, results of needs analysis instruments applied to Universidad Nacional students are provided. so that instructors can have the tools to identify the readings that students may find more meaningful and therefore improve their reading skills.
\end{abstract}

Artículo basado en una ponencia presentada en el I Congreso Internacional de Lingiäística Aplicada. llevado a cabo en octubre de 2007. en el Campus Omar Dengo. de la Universidad Nacional de Costa Rica.

Correo electrónico: anarojasugalde@yahoo.com 
Palabras clave: materiales auténticos, aprendizaje significativo, adquisición, competencia lingüística

Keywords: authentic materials, meaningful learning, acquisition, language competence

\section{Introduction}

Choosing materials is a difficult task and instructors must be aware of many aspects before selecting specific material for their students; for example, whether the level is appropriate, the activities meaningful, or the material helpful for the students to reach the stated objectives. However, other important elements are not necessarily represented in textbooks, such as the fact that readings should contain language as it is really used since students will eventually be exposed to authentic texts (texts not created for teaching purposes) outside of class. This aspect forms part of the research that has been carried out in which I have analyzed whether theories or information established by experts are present (explicitly or implicitly) in the texts available. Much of this material, although valuable. does not include a variety of authentic readings which integrate authenticity, meaningfulness, and students' needs or interests. In this project, I have applied instruments to obtain information about the kinds of texts the university students like and need to read.

The level of the book chosen is also relevant. We must ensure that the level really suits students' needs. The problem lies in that textbooks indicate the level that they were designed for, but many do not provide a description of what that level actually represents. For this reason, all exercises and material should be designed using an accepted framework of reference such as the CEFR. ${ }^{3}$

Common European Framework of Reference for Languages: Learning, Teaching. Assessment (CEFR). <http:// en.wikipedia.org/wiki/English_as_an_additional_language >. 9 July 2007. 


\section{Theoretical Framework}

There are many theories that professors should be familiar with and take into account when teaching. All that is needed is investigation, analysis, and application. I have reviewed information by various authors which will provide insights on the use of reading comprehension materials.

Textbook writing requires the consideration of many aspects, such as layout, organization of the text, the level for which it is intended and usefulness, but there is one aspect that I would like to give special attention to: the use of authentic texts (those that were not written (xclusively for language learning) for teaching reading comprehension. My interest derives from the belief that students should be taught to understand readings like the ones they may cventually need or prefer to read in their own context (outside the (lassroom) using the target language. Authenticity is an aspect that should not be set aside. Unauthentic texts (readings created for leaching purposes) often do not transmit culture with the same richness and are not as motivating as an authentic text.

Several authors have approached this topic; I will now refer to the opinion of some of the authors who favor using authentic texts. According to Grellet and Swaffar, "Authentic texts are vital; they motivate students, offer a real context. transmit the target language culture, and prepare students to read outside the classroom." "Brown also has stated that "Simplifying, or "doctoring up" an existing short story or description is therefore not only unnecessary but also is a disservice to students who are thereby deprived of original material with its natural redundancy, humor, wit, and other captivating lieatures." These authors have strong beliefs and defend the use of authentic texts. I must say that I agree with the authors when they

1 Marva A. Barnett. More thun (sic) Meets the Eve (Englewood Cliffs. New Jersey: Prentice Hall. 1989) 145.

' H. Douglas Brown. Teaching by Principles (New Jersey: Prentice Hall Regents. 1994) 299. 
refer to literary texts that were adapted. If vocabulary is changed to make it simpler, then the effect of what is being transmitted in the text changes. Many specialists oppose using unauthentic texts and a number of studies show that using material created for native speakers has its advantages. One study carried out by Vigil is described below.

In reading, Vigil (1987) found significant differences in comprehension with beginning language students who read unedited authentic texts. Not only did their comprehension skills increase, but there were also improvements in oral and written language performance. The results of these and other studies indicate that we may be underestimating the positive effects of authentic texts on both listening and reading comprehension. ${ }^{6}$

When teaching reading, we must consider all of the above aspects and our purpose or objectives. If our intention is to help our students read, then why are we simplifying texts for them? Are they going to face simplified texts in real life? Will they be able to understand and enjoy authentic readings when they encounter them in non-academic environments? If students are not trained in class to face the kind of texts they will find outside the classroom, then how will they understand the cultural connotations? Will they even feel motivated to read anything in the target language? Wouldn't it be frustrating to face different kinds of texts for the first time and not know how to go about doing it? These are questions that we will have to answer, in order to help our students deal with real life situations.

If we, as teachers, provide students with interesting and fun texts to read, our students will enjoy them more and acquire the language as a result. In order to reach language acquisition, students should be exposed to input and internalize it without even realizing it. $^{7}$ Krashen states in his acquisition theory that "in order to acquire,

J. Shrum and E. W. Glisan, Teacher's Handbook (Boston: Hcinle \& Heinle Publishers. 1994) 117. Stephen D Krashen. Principles and Practice in Second Language Acquisition (Hertfordshirc: Prentice Hall International, 1987) 10. 
two conditions are necessary. The first is comprehensible input containing $\mathrm{i}+1$ [i represents the student's current language competence and $i+1$ the next level of competence], ... and second, a low or weak affective filter to allow the input "in'." Krashen also states that the following affective variables are important for acquisition: Motivation, self-confidence, and low anxiety. ${ }^{9}$ Providing these conditions when teaching reading gives students with the chance to acquire the language unconsciously as they read. "Our intermediate students may find real texts, read for interest and pleasure, easier than our pedagogical materials. Moreover, if the above analysis is correct, it may be that free pleasure reading will result in more acquisition of the language."10 For optimal input, Krashen has proposed the following requirements: comprehensible material, interesting/relevant lexts, passages which are not grammatically sequenced, a sufficient amount to read, a low filter level (which is met if the texts are (omprehensible and interesting), and tools for conversational management. In regard to Krashen's acquisition theory, we can see lhat choosing the texts to be used in class is not a random process; in lict, we must be sure they meet the necessary standards.

Both conversation and pleasure reading have the potential of meeting the requirements for optimal input for acquisition very well. We have reached the conclusion that an interesting conversation and reading something for pleasure, are excellent language lessons. This comes as no surprise to millions of people who have acquired language using only these "methods", and have acquired them very well. ${ }^{11}$

Having a variety of authentic texts that are interesting enough thit students would like to read them even in their native language,

Krashen. 33.

Krashen. 31.

Krashen. 166.

Krashen. 167. 
and avoiding the great number of pre-reading and follow-up activities that accompany many texts, will then result in pleasure reading. This means a low affective filter, relevance, low anxiety, input with no grammar sequence, and comprehensible input $(i+1)$ resulting then in acquisition of the target language. Krashen has made it clear that the input must be relevant. To provide the students with relevant information, both our classes and the material used must be meaningful. We must always be aware of the fact that if students are exposed to materials or topics which are not appealing for them, then effective reading comprehension, in this case, will not take place. In addition, I would like to emphasize the meaning of relevance, since it is crucial. What does relevant input mean exactly? To answer this question I will refer to Ausubel who explains meaningful learning.

Meaningful learning ... may be described as a process of relating and anchoring new material to relevant established entities in cognitive structure. As new material enters the cognitive field, it interacts with, and is appropriately subsumed under, a more inclusive conceptual system. The very fact that material is subsumable, that is, relatable to stable elements in cognitive structure, accounts for its meaningfulness. ${ }^{12}$

This can be applied to the use of authentic material. If we choose texts containing aspects that students can relate to themselves, such as their social context, their feelings, or the world they have created and believe they live in, students can find a connection with the text and reading can become interesting.

We must also be aware of the necessity of keeping the reading activities meaningful as well. Ausubel's theory also refers to the fact that people keep in their long-term memory aspects which are meaningful to them, but fail to remember at a certain point those

12 H. Douglas Brown, "Human Learning," Language Learning and Teaching (New Jersey: Prentice Hall Regents. 1994) 80. 
which were not significant. ${ }^{13}$ So, if a student is taught how to skim a lext, but does not know why this strategy is used, and the text is not attractive, the student will probably fail to remember how to skim a lext. Providing a meaningful context is crucial for students to internalize the language, but if rote leaning (learning aspects in isolation) is what occurs in the class, then students are prone to forget cverything that they have learned. For example, if teachers use a text and begin extracting specific grammar points, the meaning of reading is lost, and students will be focused on trying to understand the grammar point instead of reading for pleasure and learning to read. That is, the class will no longer be reading; it will be grammar-based. In the end we may find that students are reading texts which are adapted to be grammar sequenced and interest may be completely lost. Reading must be done meaningfully; breaking up the text in pieces and isolating items will not provide students with meaningful learning. A phrase we should always remember is: "Don't kill the rading text, recognize when it is dead." 14 By this, Cory-Wright meant lhat many teachers try to "take advantage" of a text as much as possible hy focusing on grammar points, specific content and endless activities lhat students end up hating along with the reading itself. She argued lhat we must know how to work on meaningful tasks and not overload lhe students with uninteresting activities. Cory-Wright's insight reflects Ausubel's meaningful learning theory (explained above) in lice sense that reading should be pleasant and the focus should not be shifted to the individual components of the text.

Another aspect to consider when using the material we choose is the diverse learning styles that we can observe in the classroom. There are various models that provide different categories of learning styles; for example, that of Ricky Linksman states that the learning styles are Visual. Auditory, Tactile and Kinesthetic. They cannot be

\footnotetext{
Brown. 82.

11 Kate Cory-Wright. "Teacher. we hate reading!" Conference. Textos Educativos: Open House (San José. August 23. 2006).
} 
considered separately since each one should be linked to the brain hemispheric dominance (left or right). That is, according to this author, most people have one side of the brain more developed than the other due to various factors, and that side of the brain should be considered as well as the person's learning style when teaching. ${ }^{15}$ However, there are other proposals such as that of Feldger and Henriques, who have suggested the following learning styles: sensing and intuitive, visual and verbal, active and reflective, sequential and global, and inductive and deductive learners. ${ }^{16}$ Still another model states that there are seven different categories: visual, aural, verbal, physical, logical, social, and solitary. ${ }^{17}$ There are indeed many differences in these and other models; however, what must be kept in mind is that we have many students in the class, and each one may have a slightly different learning style. That is why we need to choose a variety of texts and teaching methods to approach reading comprehension. "The goal is a balanced teaching style, in all classes at all levels. Our hypothesis is that language instructors who adapt their instruction to address both poles of each of the five given dimensions should come close to providing an optimal learning environment for most (if not all) students in a class." 18

Besides learning styles, we must also consider the reading techniques that we plan to apply in the class. Brown ${ }^{19}$ has proposed several principles for designing interactive teaching techniques which are very valuable for any reading course. His principles are as follows: 1. In an interactive curriculum, do not overlook the importance of specific instruction in reading skills. 2 . Use intrinsically motivating

\footnotetext{
15 Ricky Linksman. How to Learn Anthing Quickly (New Jersey: Carol Publishing Group. 1996).

16 Richard M. Felder and Eunice R. Henriques. "Learning and Teaching Styles in Foreign and Second Language Education". Foreign Language Annals. 28. No. 1: <http://www.ncsu.edu/felder-public/ Papers/FLAnnals.pdf> (1995) 21-31.

17 Advanogy.com. Oreniew of Learning Styles, <http://www.learning-styles-online.com/overview> (2003).

Is Richard M. Felder and Eunice R. Henriques. 27.

19) H. Douglas Brown. Teaching by' Principles (New Jersey: Prentice Hall Regents. 1994) 298.
} 
1cchniques. 3. Utilize techniques with authentic language and contents. 1. Encourage the development of reading strategies. 5. Include both hottom-up and top-down techniques. 6. Consider subdividing your 1'chniques into pre-reading, during-reading, and after-reading phases. 1. Build in some evaluative aspect to your techniques.

Regarding the first principle, we must realize that assuming llat students know how to read is not the best thing to do. We must pruide them and provide time for students to have silent reading. "Sustained silent reading allows students to develop a sense of fluency. $\Lambda$ Iso silent reading then becomes an excellent method for selfIIIstruction on the part of the learner." 20 The second principle takes us hack to Ausubel and the importance of meaningfulness, and Krashen and his affective variable necessary for a low affective filter and linguage acquisition. This occurs since Brown emphasizes the need 11) choose the right techniques and texts to make learning interesting lor the students and provide learning experiences that students can Ilentify with. The third aspect, which is one of the main points of this project (and was mentioned at the beginning of this section), refers to Ilic importance and necessity of using authentic texts. The fourth and lifith principles are important because we do not intend for students 11) read without guidance; we must help them find ways in which rialding can be made easier and more productive. The sixth principle is required because if a text is not introduced, students may not be IIIcrested in it from the start. It is the teacher's duty to build curiosity ind interest however possible. Also having students carry out a task while reading (such as writing questions or short opinions in the Illargins) can help them improve their critical reading skills. The postc idling phase is a must. It would be awkward to assign a reading and lilter do nothing with it. Debates are a good option, as well as roleplilys, and many other activities. Of course, the tasks will depend on llic type of text that you bring to the class. The last principle has to do

Brown. 298. 
with assessing the students' reading comprehension. Brown says that reading is "totally unobservable" ${ }^{21}$; instead, we must refer to responses that indicate comprehension such as doing, choosing, answering, condensing or conversing. Therefore, skills must be integrated to enable students to use other skills to show their understanding of a text. For example, if students are to create a role-play about a certain story, they need to understand what they have read to carry out the task.

Finally, I will refer to the main points stated in this section with the purpose of finding facts that will lead me to an accurate conclusion on the use of authentic texts in the classroom. First, authentic texts provide students with reason to read, cultural insight, and input for natural language use. This will stimulate pleasure reading since students feel they are not reading simply for a final grade. Thus, they will be reading for the same purpose they would in their native language. For students to enjoy the texts, they must identify with them, as Ausubel's meaningful learning theory suggests. The instructor must also be cautious in the selected tasks by considering Brown's principles for designing interactive reading techniques. However, if the teacher does not vary the different tasks and/or approaches to teaching in order to fit various learning styles, only a few learners benefit, so a variety of ways should be used. Having accomplished all of the above, students will be highly motivated, have a low-affective filter, and enjoy their reading; this takes us back to Krashen, who states that reading for pleasure will result in acquisition of the target language. In view of the information discussed above, teaching reading is not a simple task. Nevertheless, as instructors apply all of these relevant theories, they will notice that it becomes simpler as they gain experience, since they actually will be training themselves to teach more efficiently with the most effective resource: authentic material.

i) Brown, 300. 


\section{Assessing existing textbooks and analyzing student needs}

\section{Assessing textbooks in the market}

Reading, as one of the four basic skills, has been studied in (letail by different linguists and many textbooks have been published with the aim of teaching reading comprehension to students of different ages. In this section, I will present the textbooks with the best results (1) an evaluation of different types of textbooks sold in the market loday. In regards to our specific context, the Universidad Nacional has been carrying out projects for a number of years. A variety of material is being used in different fields for reading comprehension; however, these texts have not yet been evaluated by the corresponding linguage experts in the university. In the university library, Biblioteca Iociquin García Monge, there are five reading comprehension books which were published in Costa Rica. ${ }^{22}$ I have analyzed these five hooks and eleven others, most of which were published in the U.S. ${ }^{23}$

\footnotetext{
Textbooks published in Costa Rica: Xinia Chacón A. and Agnes Flores G.. English Reading Comprehension Tools. (Heredia: EUNA. 2001): Ana Soto M., Ileana Villalobos E.. and Lelia Villalobos R.. Prácticas de e'aluación: comprensión de lectura en inglés (Heredia: EUNA. 1997): José Otilio Umaña Ch.. Improving Academic Reading in English (Heredia: EUNA. 1996): Olga Marta Murillo U.. Lectura èn inglés (San José: EUNED. 2002): y Inglés básico: comprensión de lectura. (San José: EUNED. 1997).

Texthooks published abroad: Albert K. Ridout and Jesse Stuart (eds.). Shon Stories for Discussion (New York: Charles Scribner`s Sons, 1968): Anita Stern. Tales From Many Lands: An Antholog! of Multicultural Folk Literature (Lincolnwood, IL: National Textbook Company. 1996): Anita Stern. World Folktales: An Anthology' of Multiculural Folk Literature (Lincolnwond. IL: National Texthook Company, 1994): Burton Goodman. Goodman s Five-Star Stories: Chills, More Chills (Chicago. IL: Jamestown Publishers, 1997): Burton Goodman, Literature For English (Chicago. IL: McGraw-Hill Contemporary. 2003): Cheryl Pavlik, Read Smart (New York: McGraw-Hill Companies, 2004): Henriettal C Dunham, and Catherine Vaden Summers. eds., English Integrated: An Adranced Reader/Grammar for Learners of English (Boston: Little. Brown and Co., 1986): Henry Billings. Melissa Billings. John F. Warner and Margaret B. Warner. Critical Reading Series: Apparitions (Chicago. IL: Jamestown Publishers. 1999); Henry Billings and Melissa Billings, Critical Reading Series: Phenomena (Chicago. IL: Jamestown Publishers, 1999); Jack C Richards and Samuela Eckstut-Didier. Strategic Reading (Hong Kong. China: Cambridge University Press. 2003): Terence J Fitzgerald. Carroll Moulton. and Sari Wilson, eds., The Holt Reader: An Interactive Worktext (Fortworth, TX: Holt. Rinehart, and Winston. 2003).
} 


\section{Textbooks with the most positive results (according to the instrument used)}

To summarize the findings of the evaluations, I would like to mention the two textbooks with the best results according to the instrument used. ${ }^{24}$ These are The Holt Reader and Strategic Reading. The Holt Reader presents texts which are authentic pieces of literature. It includes short stories, poems, essays, speeches and a play. It has many activities in which the students must use critical thinking skills and really interact with the text. It also has a section where students can relate what they have read to their own lives. The disadvantage I found was that it does not include texts other than famous literary texts, so there is little variety in the sense of including songs or jokes. In addition, it focuses only on American culture; it does not include the four skills or all learning styles, and it does not use the CEFR guidelines as a basis for choosing the readings.

Strategic Reading does not focus on literary passages or any authentic material, though it has one major advantage in comparison with the rest: it provides the students with varied, meaningful tasks. Cultural diversity is included, grammar is not taught explicitly, the text promotes interaction, and the majority of the topics appear interesting for young adults and adults. The main problem with this material is that the texts are not authentic and most of them, although interesting, are magazine-type articles. Another aspect is they were not chosen based on the CEFR guidelines and the listening skill is excluded from the skills students must use in the exercises.

\section{Results of the needs analysis obtained from the instrument applied $^{25}$}

In order to choose the most appropriate texts for the population of this project, I carried out a needs analysis survey to find out what

\footnotetext{
It The instrument used was adapted from the "Textbook Evaluation Instrument" designed by students and professor Lelia Villalobos in the course Evaluación de material linguiístico comercial en inglés (Maestría en Segundas Lenguas y Culturas con énfasis en ingles como lengua extranjera: Alumnado adulto. UNA, 2006). This instrument is too long to be included here. but may be obtained by writing 25. to my e-mail address. A detailed account of these evaluations will be published elsewhere.

25. See Appendix 1.
} 
students like and need to read in their native language. In this way, my material will be created considering students' real interests and nceds. The instrument was applied to UNA students who were taking reading courses required for their major. The students' ages range between 18 and 35 years, with 55 men and 45 women for a total of I()0 surveys.

Table 1. The graph represents the top five choices of the male and female students.

Number of

students

Texts of preference for males $\square$ Texts of preference for females

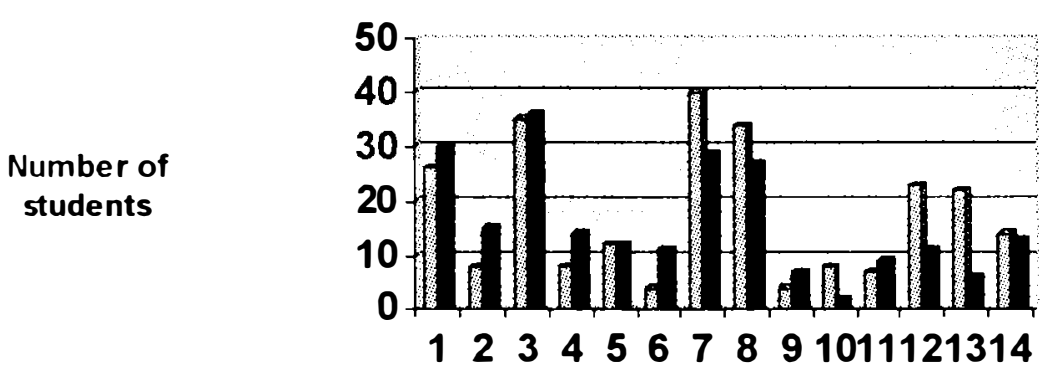

Types of texts

These results suggest that students do like reading articles from the newspaper and magazines. but may leel less motivated because they like other types of texts as well and do not find them in the textbook they use. In other words, they receive too much input of the same kind and this can make reading boring and the learning process less effective. 


\section{Table 2. The graph shows the results obtained from both females and males together.}

\section{Number of students}

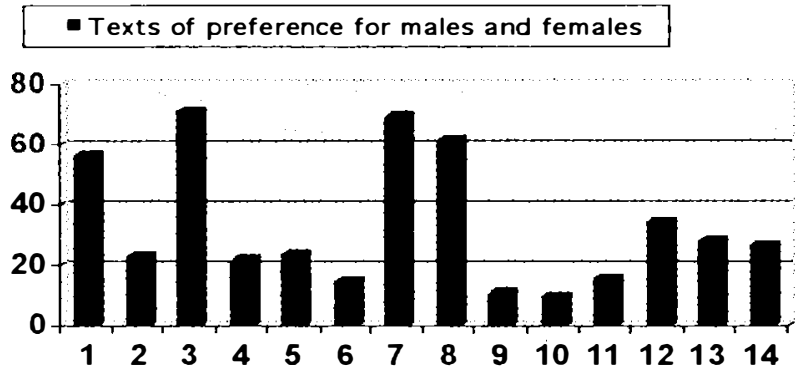

Types of texts

Types of texts: 1. novels, 2. poems. 3. short stories. 4. self-help books. 5. songs. 6. cards. 7 . newspapers. 8. magazine articles. 9. horoscopes. 10. advertisements. 11 . movie critics. 12. comic strips. 13. jokes. 14. others.

Other options mentioned by men: historical facts. science fiction. erotic stories. sports. true stories. art. documentaries. information about cars. theology.

Other options mentioned byomen: the Bible. cultural aspects. plays. mythology. philosophy. math. historic facts, reflections, art. technology.

I have separated the information provided by males and females since I believe that they have different preferences. Therefore. if we have a class where the majority of the students are of one particular gender, we must choose most of texts considering their gender and what they prefer. Of course. the instructor can prepare a specific needs analysis instrument and collect information on the group s particular interests and needs.

The following graphs show the information collected from the same students described above. However, in this case the data refer to the top five texts students frequently were required to read. 


\section{Table 3. The graph represents the top five choices of the male and female students.}

Texts male students need to read Texts female students need to read

Number of students

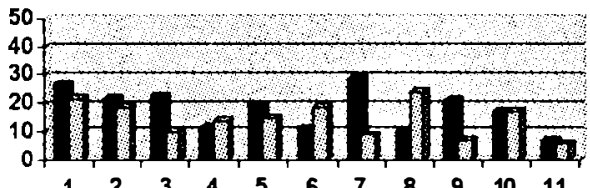

Types of texts

\section{'Iable 4. The graph shows the results obtained from both females and males together.}

Number of students

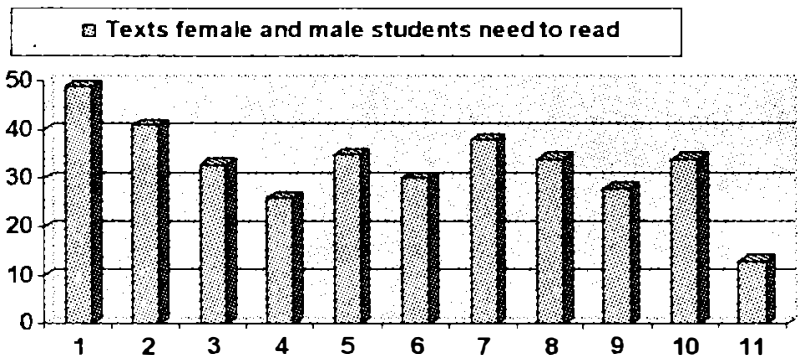

Types of texts

lipe's of texts: 1 . nutritional information on food labels; 2 . brochures about health topics; 3 . Irrochures with information about products; 4 . brochures with information about hotel and Inurist sites: 5. menus: 6. instructions on food preparation; 7. building and assembly IIIstructions: 8. instructions for daily products such as creams or shampoo; 9. electrical ippliance manuals; 10 . friendship and love letters; 11 others.

MI'n's options: the Bible. academic material for their studies. brochures from art exhibits and Iuurist sites. warning signs

W'omen's options: academic material for their studies 
The graphs presented above clearly show that students do read magazine and newspaper articles, which are among their top preferences; there are, however, other types of textsthat students enjoy to read and have marked as their five favorites.

\section{Conclusion}

A book is never the main focus of a course since learning is not based on following a textbook, but it will provide the teacher with the tools for a successful class. It is the instructor's job to create a good teaching-learning environment and promote motivation within the group. This cannot be done with any book on its own, but a very good one would indeed be of great value.

Moreover, although the basis of a course may be reading, we can integrate speaking, writing and listening. Instructors should not be afraid to make a change and develop material that they consider appropriate for their students. They do not have to accept the textbooks offered in the market, except when these materials are mandatory in the institution where they work. However, even in this case, professors can include additional readings and tasks, or modify the ones presented in the textbook.

It is essential to develop materials that are appropriate for Costa Rican students, where students are exposed to texts like those that they will eventually encounter in "real life" and learn how to understand them. We, as professionals in the field, must continuously try to find the best way to teach and share our experiences - and the material we use-in order to receive feedback and provide others with everything that we have learned. We must never stop creating materials and contributing to the field of language teaching in order to improve the quality of education in our country. We should never forget that we influence and form part of education in Costa Rica in one way or another. Therefore, we must do our best to teach our children, teenagers, young adults, and future English teachers, and thus transmit, create, and improve the field as much as possible for the benefit of the country. 


\section{Appendix 1: Survey (designed by author)}

Instrumento para obtener datos de textos que leemos por necesidad o preferencia

I.lene los espacios con la información correspondiente.

I. Sexo: $F$ $\mathrm{M}$ 3. Ocupación:

$\therefore$ Edad: 4. Carrera que cursa en la UNA:

l 'onteste la pregunta marcando las opciones que corresponden a su resfuicsta.

I.() ¿Qué tipo de documentos le gusta leer? Marque todas las opciones que rorrespondan.

$\begin{array}{ll} & \text { Novelas } \\ & \text { Poemas } \\ & \text { Historias cortas } \\ & \text { Libros de autoayuda } \\ & \text { Canciones } \\ \text { Tarjetas } & \text { Artículos de periódico } \\ & \text { Artículos de revistas } \\ & \text { Horóscopos } \\ & \text { Anuncios } \\ & \text { Críticas de películas } \\ & \text { Tiras cómicas } \\ & \text { Chiste } \\ & \text { Otro tipo de texto que le gusta leer: }\end{array}$

1.I Anote 5 de las opciones que marcó en la pregunta anterior en orden de preferencia. Si marcó menos de 5, escriba solamente las que marcó. 1 =Mayor preferencia $/$ 5=Menor preferencia.

1.

2. 
3.

4.

5.

2.0 De los siguientes tipos de textos, ¿cuáles lee con frecuencia?

Información nutricional en etiquetas de alimentos
Brochures con temas de salud
Brochures con información de productos
Brochures con información de hoteles o lugares turísticos
Menús
Instrucciones para preparar algún alimento
Instrucciones para armar cosas
Instrucciones para usar productos de uso diario como cre-
mas o shampoo
Manuales de uso de electrodomésticos
Cartas amistosas o de amor
Otro tipo de texto que necesito leer:

2.1 Anote 5 de las opciones que marcó en la pregunta anterior en orden de frecuencia. Si marcó menos de 5 opciones, escriba solamente las que marcó. 1 =Mayor frecuencia $/ 5=$ Menor frecuencia

1.
3.
4.
5. 